\title{
Microcystin Accumulation and Potential Depuration on Muscle of Fishes of Fish Farm: Implications to Public Health
}

\author{
Camila Ferreira Mendes'; José Etham de Lucena Barbosa²; Janiele França Nery ${ }^{3 *}$ \\ ${ }^{1,2}$ Universidade Estadual da Paraíba, Laboratório de Ecologia Aquática - LEAq \\ Rua Baraúnas, 351 - Bairro Universitário - Campina Grande - PB CEP 58429-500 \\ ${ }^{3}$ Instituto Federal de Educação da Paraíba- campus Picuí - Acesso Rodovia PB 151 \\ s/n Bairro: Cenecista Cidade/UF: Picuí/PB \\ *janiele.biologa@gmail.com
}

\begin{abstract}
This study investigated the bioaccumulation of microcystin on muscle of O. niloticus of fish farms of Brazilian semiarid reservoirs and their potential depuration of MCYST on fish's muscle during ontogenetic fish development. Only one sampling was conducted in January 2012 in the five reservoirs located at Braziliam semiarid region. MCYST were detected in the waters of the all reservoirs and in $60 \%$ of the fish muscle samples. Significant differences were observed in MCYST concentrations for fish ontogenetic stages $(p<0,05)$. Most MCYST concentration were observe in early fish stages. For an adult human weighing $60 \mathrm{~kg}$ ingesting $300 \mathrm{~g}$ of fish muscle this MYCST level at fish on early fish stage phase represents an estimated daily intake (EDI) of 0,02 $\mu \mathrm{g} / \mathrm{kg}$ of body weight. In juvenile and adults the levels of MCYST represent a daily intake of 0,005 and 0,001 $\mu \mathrm{g} / \mathrm{kg}$ respectively, and $\mathrm{np}$ represent risk for consumers. However should be avoided consumption of fish when it confirmed the presence of microcystin already in the water. Both the control of eutrophication and the proper management of fish farming activity can serve as preventive measures in controlling algal blooms and their consequent risks to public health.
\end{abstract}

Keywords: Cyanobacteria; Cianotoxyn; Oreochromis niloticus; semiarid region.

\section{INTRODUCTION}

The occurrence of toxic cyanobacterial blooms in eutrophic lakes and reservoirs is a world-wide problem (PAERL et al., 2001). In semiarid region Lakes and reservoirs are subject to important periods of water shortages. In this region, reservoirs present low outflow and high water residence time associated with a negative hydric balance and high temperatures during most of the hydrological cycle. This intensifies the accumulation and concentration of nutrients, making these systems considerably more vulnerable to eutrophication and cyanobacterial blooms than reservoir in more humid areas (BARBOSA et al., 2012)

Cyanobacteria, in aquatic ecosystems, may produce secondary metabolites such as the hepatotoxins, microcystins (MCYST). While MCYST have been quantified in numerous aquatic consumers (MAGALHÃES et al, 2003; SOARES et al, 2004; KARJALAINEN et al, 2005; GERARD $e t$ al, 2009; BERRY \& LIND, 2010; DEBLOIS et al., 2011; VASCONCELOS et al., 2013) across a variety of ecosystems, there is still debate whether biomagnification or biodilution of MCYST generally occurs in aquatic foodwebs.

Fish, at the top of the aquatic food chain, are likely to be most affected by exposure to MCYST, and thus their consumption may pose a great risk to humans (MAGALHÃES et al., 2001). In farm fishes, with conditions of confinement, or during extended blooms of toxic cyanobacteria in reservoirs, the decrease of predation may not be sufficient to protect these species and other planktivorous fish an acute intoxication by toxins. Thus farm fishes is an important activity to obtain protein for the world population and may be compromised by cyanobacterial blooms (VASCONCELOS et al., 2013).

Among the many exotic fish species, Nile tilapia (Oreochromis niloticus (L.)) is between the main species cultivated and stocked in lakes and reservoirs in semiarid. The success of tilapia in that environment is especially so for their omnivorous feeding habits, flexibility in growth rate and maturation size and broad environmental tolerances and flexible habitat requirements (ATTAYDE et al., 2011). Furthermore, tilapia is omnivorous and microphages organisms, which basically consumes plankton and detritus in suspension (LAZZARO, 1987). 
It is seen that the accumulation of toxins in fish can occur at different intensities at different stages of development of organisms, it seems to be easier the accumulation in young life stage (DEBLOIS et al., 2011). Toxins depuration in individuals can vary due to the metabolism of the fish and its life stage as the type strain produced by toxic bloom that is present in the organism (CHEN et al., 2006).

Consuming microcystin-contaminated water or seafood poses a risk to human health. To protect consumers from the adverse effects of cyanobacterial toxins the World Health Organization (WHO) established the maximum allowable concentration (MAC) for MYCs in drinking water as $1 \mu \mathrm{gL}^{-1}$ and a tolerable daily intake (TDI) of $0.04 \mu \mathrm{g} / \mathrm{kg}$ of body weight (bw)/day, as a provisional guide line (WHO, 1998). It was assumed that $80 \%$ of the MCYST that were ingested on a daily basis came from contaminated drinking water and there meaning $20 \%$ was in taken from food or inhalation (DIETRICH AND HOEGER, 2005).

The major objectives of this study were: (1) measure levels of MYC on muscle of O. niloticus of fish farms of Brazilian semiarid reservoirs, (2) to investigate potential depuration of MYC on fish's muscle during ontogenetic fish development (3) to evaluate the potential risk of the contaminated fishes to human health.

\section{Materials AND Methods}

\subsection{Study Area and Sampling Sites}

The study was conducty in five reservoirs located in braziliam semi arid region (Figure 1). These reservoirs were select for intense survey of cyanobacteria and presence of fish farm. The reservoirs are used to water supply population. In the last years, the fishs farming has grown into an intensive and highly form of aquiculture, specially $O$. nilloticus culture in this reservoirs.

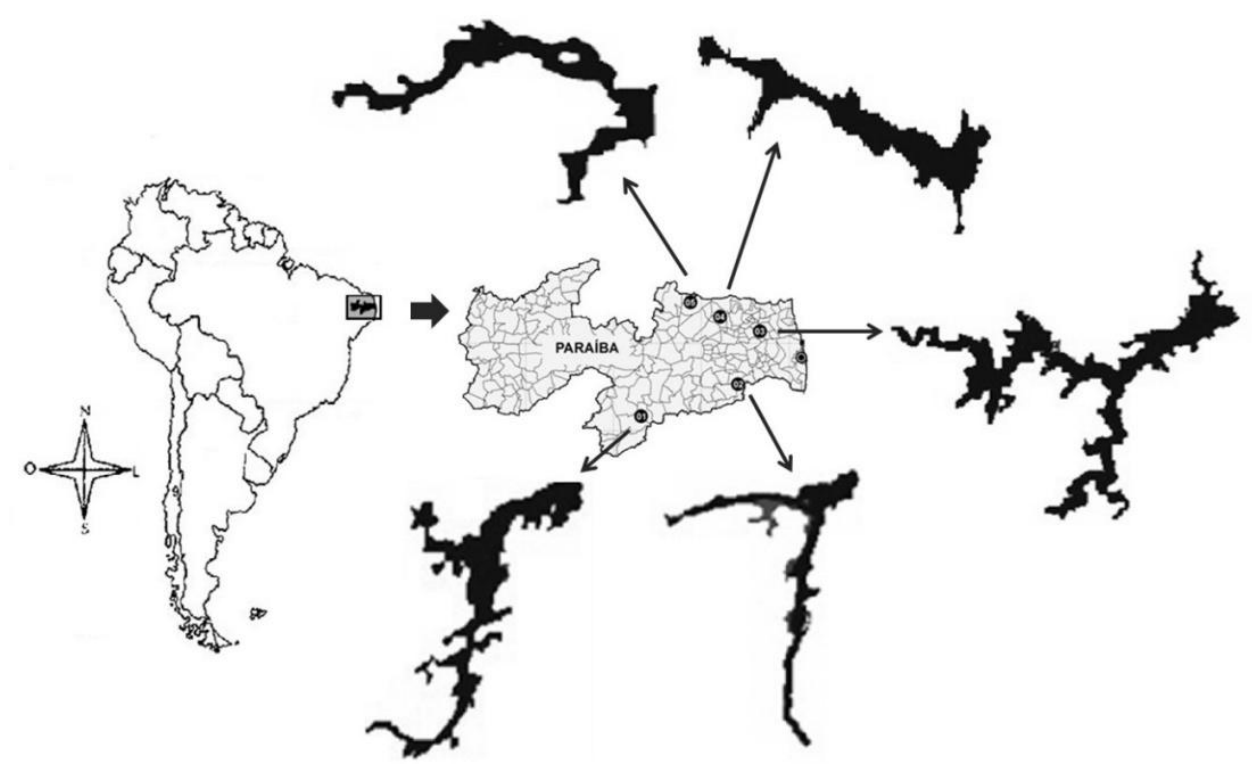

Figure1. Representative location of sampling points at Braziliam semiarid region

\subsection{Limnological Variables}

Only one sampling was conducted in January 2012 in the five reservoirs. Environmental samples and phytoplankton were collected by a Van Dorn Bottle 10-20 cm the water surface at three sites next the fish farming region at the reservoirs. Environmental variables evaluated were: water temperature, $\mathrm{pH}$, dissolved oxygen (HORIBA U-50) and water transparency (Secchi disk). The water samples were collected in PVC bottles previously cleaned with deionized water and stored in recipients containing ice for transportation to the lab, where they were frozen and nutrients (inorganic dissolved nitrogen and total phosphorous) were examined according to the procedures described by APHA (1992). Chlorophyll-a concentrations were determined spectrophotometrically based on the procedures described in APHA (1995). Sub samples $(300 \mathrm{~mL})$ were preserved in lugol solution and observed under an inverted microscope using 525 - $\mathrm{mL}$ sedimentation chambers for cyanobacteria identification and quantification (UTERMOHL, 1958). Cyanobacterial genera and species were identified by microscopic observation by distinguishing morphological characters cited in the literature (KOMAREK AND AGNOSTIDIS, 1986; Baker, 1991, 1992). 


\subsection{Fish Sampling}

For each reservoir 30 individuals of Oreochromis niloticus were collect, in different maturation phases and time to exposition to algal blooms on reservoirs (early life stage - one month on reservoir; juvenile phase - three mounts on reservoirs; adult phase - most that six month on reservoir). The fishes were frozen and the muscles were extracted on laboratory. The stomachs were extracted, open and the content classified and conserved on alcohol.

\subsection{MCYTS Determination}

The determination of MCYST in the natural water samples was done using a commercially ELISA Microcystin Plate Kit (ENVIROLOGIX INC.®).

To determination of MCYST on fish's muscle, samples (20g) were minced and homogenized with in $20 \mathrm{ml}$ of $0,1 \%$ (v:v) methanol TFA. The sample was then centrifuged at 11,000×g and the supernatant collected and stored in a becker. The pellet was reextracted twice and the supernatants were pooled together (final volume of $30 \mathrm{ml}$ ). The extracts were filtred vaccum onto fiberglass filters. The filtrates were totally evaporated and then ressuspended in Mili Q water. The filtered was passed through a C18 cartridge. This cartridge was washed and eluted with Mili Q water, with methanol $20 \%$, with methanol $30 \%$ and then with methanol TFA $0,1 \%$. This last fraction was evaporated and ressuspended to the appropriated concentration for determination. Muscle and viscera samples were analyzed by immunoassay using the ELISA Microcystin Plate Kit (ENVIROLOGIX INC.®).

\subsection{Data Analyses}

Differences spatial gradients to limnological variables, MCYST concentrations were tested by Student test. Pearson correlation analysis was run to detect correlations between densities of cyanobacteria on stomach and MCYST on muscle of fishes. All these analyses were run with the aid of the software Statistica 7.0.

\section{RESUltS}

The main limnological characteristics of the reservoirs were summarized in table 1 . All reservoirs presented water temperature around $28^{\circ} \mathrm{C}$ without thermal stratification. The values obtained to dissolved -oxygen concentration indicated the existence of oxygenated water columns. The water $\mathrm{pH}$ is alkaline showing little variation through the reservoirs. Light penetration was low in Acauã water's, and high in Cordeiro reservoir (table 1). Ammonium is the most abundant nitrogen nutrient form in all reservoirs. Acauã reservoir is the most eutrophic reservoir although, no significant differences were observed to phosphorus $(\mathrm{p}=0,54)$, nitrogen $(\mathrm{p}=0,41)$ or clorophyll $(\mathrm{p}=0,8)$ concentrations among the reservoirs (table 1).

Table1. Limnological Variables (mean \pm SE) measured in five reservoirs located at Braziliam semiarid region

\begin{tabular}{|c|c|c|c|c|c|c|c|c|c|c|c|c|c|c|c|}
\hline $\begin{array}{l}\text { Limnological } \\
\text { Variables }\end{array}$ & \multicolumn{3}{|c|}{ Acaua } & \multicolumn{3}{|c|}{ Araçagi } & \multicolumn{3}{|c|}{$\begin{array}{l}\text { Boqueirão do } \\
\text { Cais }\end{array}$} & \multirow{2}{*}{\begin{tabular}{|l}
$\begin{array}{l}\text { Cacimba } \\
\text { de Varzea }\end{array}$ \\
1.2
\end{tabular}} & \multirow[b]{2}{*}{ \pm} & \multirow[b]{2}{*}{0.0} & \multicolumn{3}{|c|}{ Cordeiro } \\
\hline $\begin{array}{c}\text { Water } \\
\text { transparence }(\mathrm{m})\end{array}$ & 0.8 & \pm & 0.0 & 1.5 & \pm & 0.1 & 1.1 & \pm & 0.0 & & & & 2.4 & & 0.0 \\
\hline $\begin{array}{c}\text { Water temperature } \\
\left({ }^{\circ} \mathrm{C}\right)\end{array}$ & 28.2 & \pm & 0.1 & 28.7 & \pm & 0.1 & 27.1 & \pm & 0.3 & 27.5 & \pm & 0.1 & 26.2 & \pm & 0.0 \\
\hline $\mathrm{pH}$ & 9.1 & \pm & 0.2 & 8.7 & \pm & 0.1 & 8.9 & \pm & 0.1 & 8.9 & \pm & 0.1 & 8.5 & \pm & 0.3 \\
\hline $\begin{array}{c}\text { Dissolved Oxygen } \\
(\mathrm{mg} / \mathrm{L})\end{array}$ & 6.4 & \pm & 0.1 & 5.6 & \pm & 0.5 & 5.7 & \pm & 1.3 & 5.2 & \pm & 1.0 & 6.8 & \pm & 0.5 \\
\hline Amonium $(\mu \mathrm{g} / \mathrm{L})$ & 261.9 & \pm & 176.2 & 721.9 & \pm & 110.9 & 444.2 & \pm & 340.4 & 87.1 & \pm & 2.4 & 78.2 & \pm & 10.8 \\
\hline Nitrite & 16.6 & \pm & 1.0 & 18.0 & \pm & 0.4 & 17.5 & \pm & 1.1 & 18.3 & \pm & 0.8 & 28.9 & \pm & 1.1 \\
\hline Nitrate & 63.0 & \pm & 1.6 & 67.1 & \pm & 5.3 & 63.1 & \pm & 2.9 & 57.6 & \pm & 5.8 & 81.5 & \pm & 5.3 \\
\hline $\begin{array}{l}\text { Total Nitrogen } \\
(\mu \mathrm{g} / \mathrm{L})\end{array}$ & 925.1 & \pm & 26.8 & 836.5 & \pm & 80.8 & 1220.4 & \pm & 344.9 & 1136.1 & \pm & 34.6 & 774.6 & \pm & 181.0 \\
\hline $\begin{array}{c}\text { Soluvel Reative } \\
\text { Phosphorus } \\
(\mu \mathrm{g} / \mathrm{L})\end{array}$ & 106.3 & \pm & 10.3 & 61.6 & \pm & 2.0 & 84.9 & \pm & 14.7 & 95.6 & \pm & 6.9 & 48.9 & \pm & 11.4 \\
\hline $\begin{array}{c}\text { Total Phosphorus } \\
(\mu \mathrm{g} / \mathrm{L})\end{array}$ & 433.6 & \pm & 5.4 & 429.1 & \pm & 1.0 & 427.4 & \pm & 9.8 & 437.4 & \pm & 6.7 & 429.1 & \pm & 12.5 \\
\hline Chlorophyll -a & 31.3 & \pm & 1.1 & 5.8 & \pm & 0.0 & 17.2 & \pm & 3.5 & 5.7 & \pm & 2.6 & 1.2 & \pm & 1.4 \\
\hline
\end{tabular}


The phytoplankton community of the reservoirs is represented by a total of 27 taxa (species and genus), from the following groups: Cyanobacteria, Chlorophyta, Bacillariophyta and Euglenophyta (figure 2A). The Cyanobacteria group was represented by a 12 taxa (Aphanizomenon issatschenkoi (Usacev), Proshkina-Lavrenko Chroococcus turgidus (Kützing) Nägeli Coelomoron tropicale P.A.C.Senna, A.C.Peres \& Komárek Cylindrospermopsis raciborskii (Woloszynska) Seenayya \& Subba Raju Merismopedia glauca (Ehrenberg) Kützing Microcystis protocystis W.B.Crow Oscillatoria limosa C.Agardh ex Gomont Planktothrix agardhii (Gomont) Anagnostidis \& Komárek Planktothrix isothrix (Skuja) Komárek \& Komárková Pseudanabaena catenata Lauterborn Pseudanabaena galeata Böcher, Sphaerocavum brasiliense De Azevedo \& C.L.Sant' Anna), All species observed are potential cyanobacterias producers of (MCYST), except for C. turgidus and $S$. brasiliense.

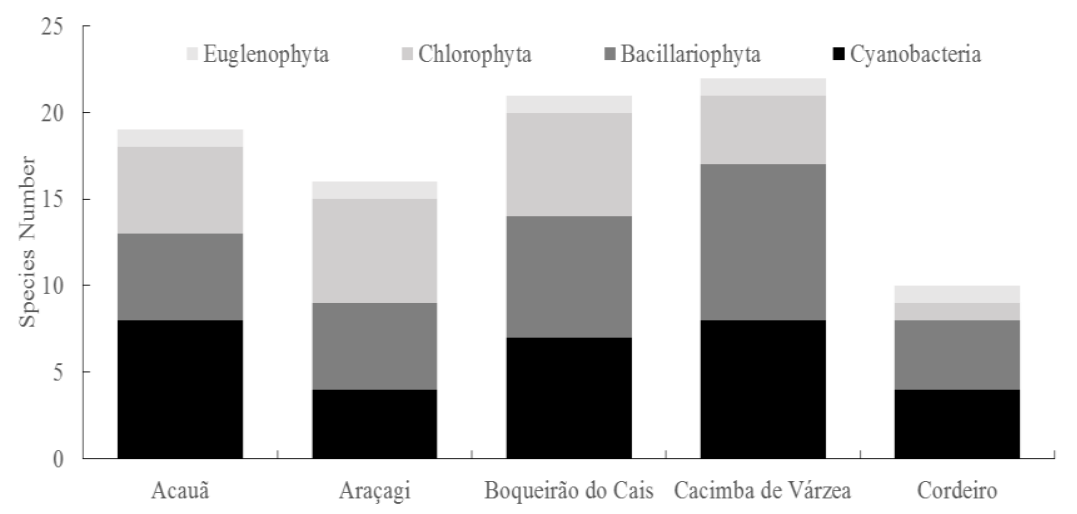

A

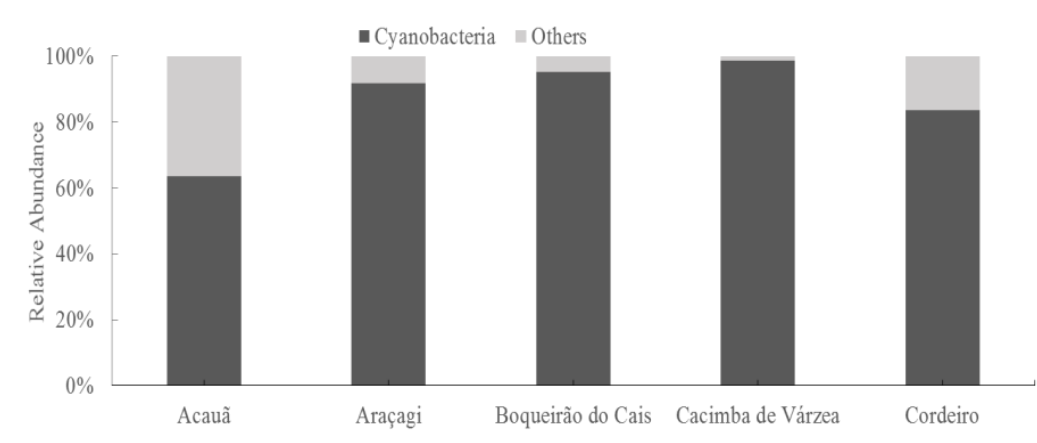

B

Figure2. Species Number (A) and Relative abundance $(B)$ of phytoplankton on five reservoirs at Braziliam semiarid

Cyanobacteria was the most abundant phytoplankton group in reservoirs (figure 2B), the highest densities occurred in Boqueirão do Cais reservoir $(X=627.353 \mathrm{Cel} / \mathrm{mL})$ followed by Cacimba de Várzea reservoir $(X=520.889 \mathrm{Cel} / \mathrm{mL})$, Acauã reservoir $(X=271.231 \mathrm{Cel} / \mathrm{mL})$, Cordeiro reservoir $(\mathrm{X}=260.662 \mathrm{Cel} / \mathrm{mL})$ and Araçagi reservoir $(\mathrm{X}=201.707 \mathrm{cel} / \mathrm{mL})$. C. raciborskii were dominant for all reservoirs except to Cordeiro reservoir where M. protocystis was dominant.

MCYST were detected in the waters of the all reservoirs. The highest concentrations was observed in Boqueirão do Cais water's $(3,2 \mu \mathrm{g} / \mathrm{L} \pm 0,8)$, following the Cordeiro water's $(2,7 \mu \mathrm{g} / \mathrm{L} \pm 0,4)$, Acauã water's $(1,3 \mu \mathrm{g} / \mathrm{L} \pm 0,6)$, Cacimba de Várzea water's $(1,1 \mu \mathrm{g} / \mathrm{L} \pm 0,2)$ and Araçagi water's $(0,9 \mu \mathrm{g} / \mathrm{L} \pm 0,4)$.

MCYST were detected in $60 \%$ of the fish muscle samples. Significant differences were observed in MCYST concentrations for fish phases $(\mathrm{p}<0,05)$. In early life stage, the concentration varied from $0,01 \mathrm{ng} / \mathrm{g}$ at Araçagi reservoir to $0,05 \mathrm{ng} / \mathrm{g}$ at Cacimba de Várzea reservoir (fig 3A). In juvenil phase it varied from $0,0 \mathrm{ng} / \mathrm{g}$ at Araçagi reservoir to $0,04 \mu \mathrm{g} / \mathrm{g}$ at Boqueirão do Cais (Figure 3B), and to adult phase the MCYST range from 0,00ng/g at Cordeiro reservoir to 0,03 ng/g at Araçagi reservoir (fig 3C). The highest value to MCYST in fish muscle, independent of fish phase, was found at Cacimba de Várzea reservoir. No differences were observed for concentration of MCYST between reservoirs. 


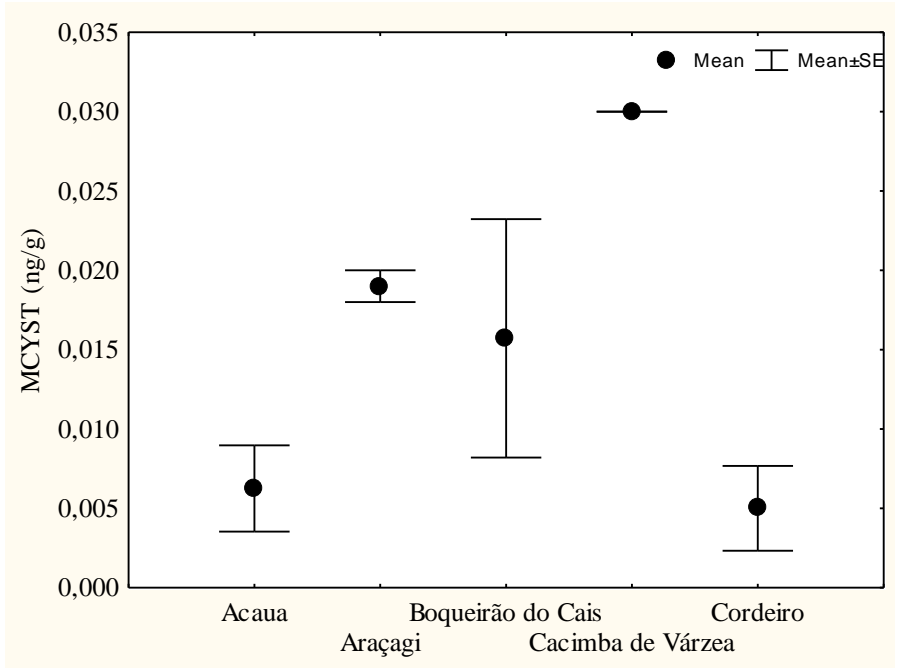

A

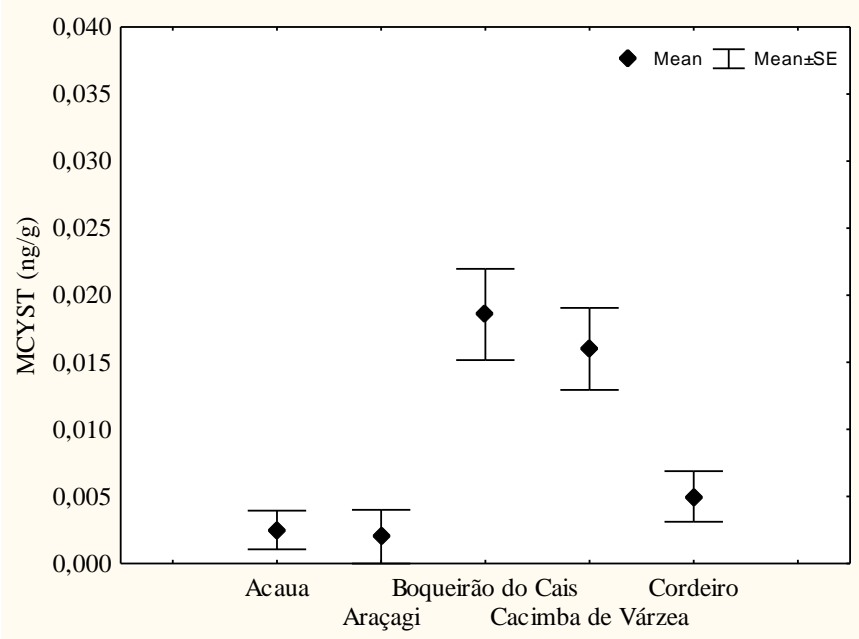

$\mathrm{B}$

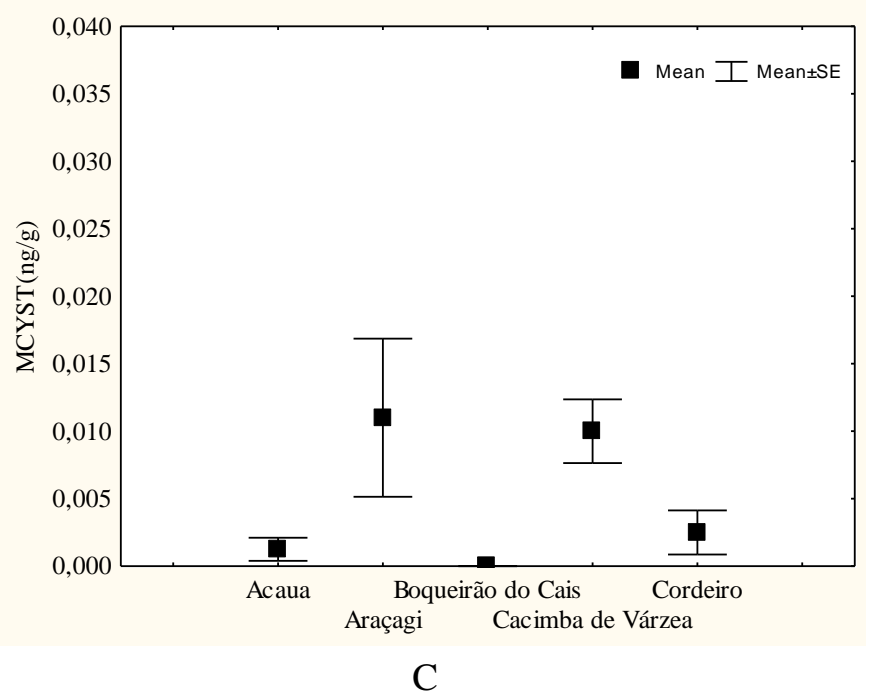

Figure3. MCYST concentration on muscle of $O$. niloticus on early fish stage (A), juvenile $(B)$ and Adult $(C)$ stages on five reservoirs at Braziliam semiarid

For an adult human weighing $60 \mathrm{~kg}$ ingesting $300 \mathrm{~g}$ of fish muscle this MYCST level at fish on early fish stage phase represents an estimated daily intake (EDI) of $0,02 \mu \mathrm{g} / \mathrm{kg}$ of body weight. In juvenile and adults the levels of MCYST represent a daily intake of 0,005 and $0,001 \mu \mathrm{g} / \mathrm{kg}$ respectively.

About $92 \%$ of the sampled stomachs were with food remains. The overall diet of T. niloticus on the fish farms consisted mainly of phytoplankton. To young life stage and juvenile phase, independent of 
the reservoir, $P$. agardhii was the most abundant diet item and to adult phase Aulacoseira granulata was abundant followed by Planktothrix agardhii e Pseudoanabaena sp. MCYST concentration on muscle are associated with Cyanobacteria densities on stomach directly to early life stage and inversely to juvenile and adult phases (figure 4).

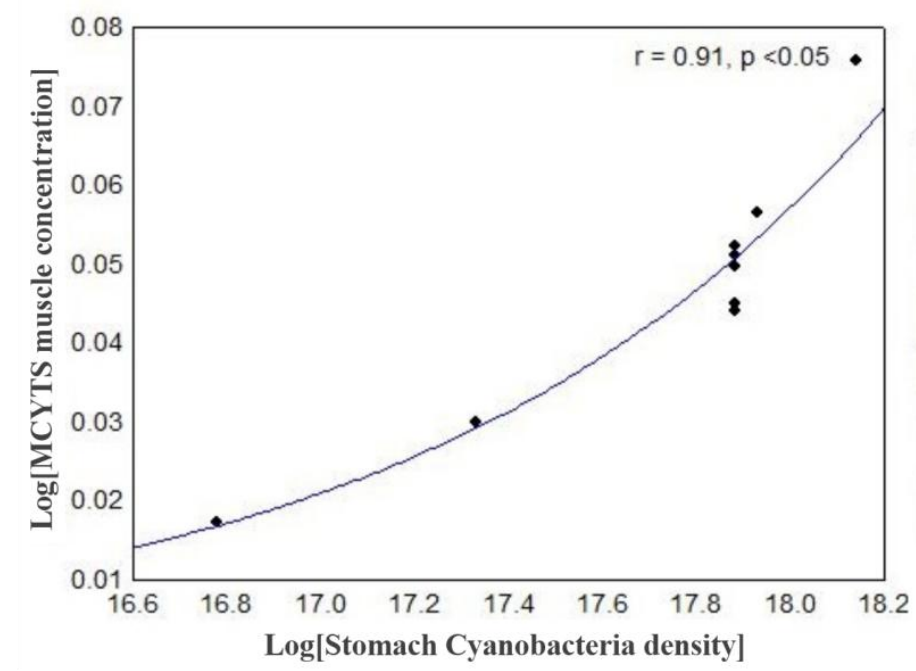

A

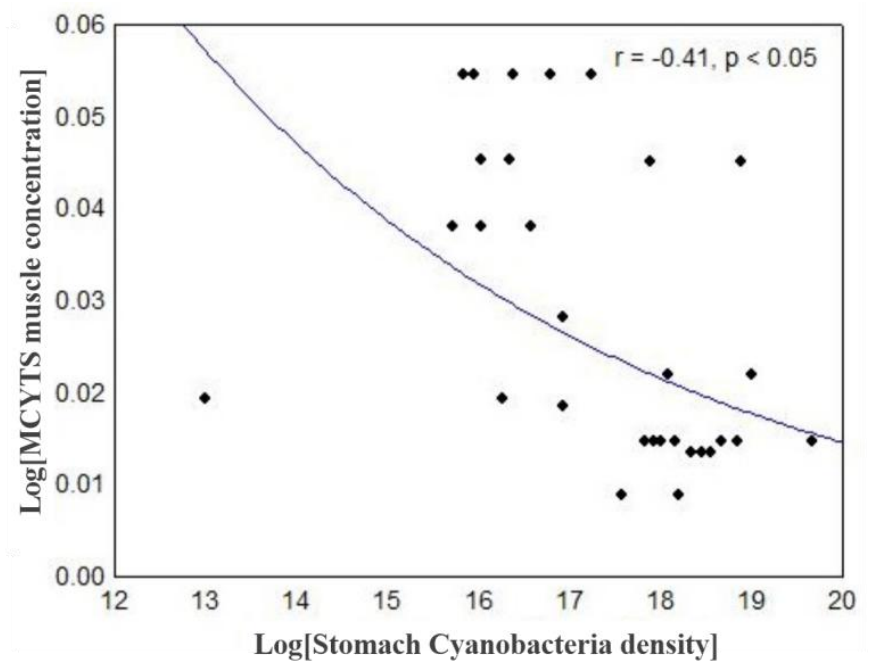

$\mathrm{B}$

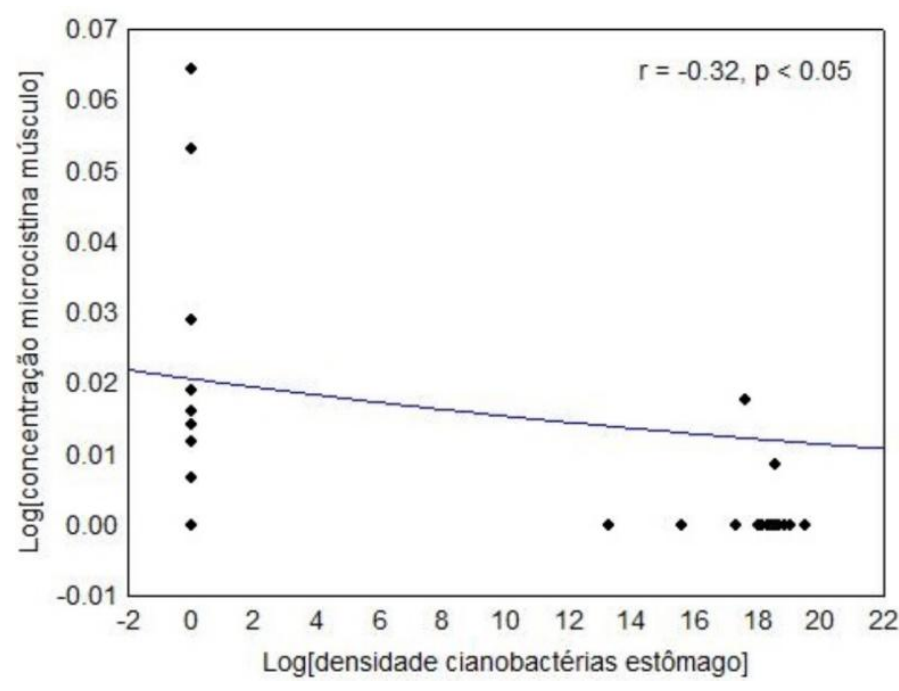

$\mathrm{C}$

Figure4. Linear regression between Cyanobacteria densities on fish stomach and MCYST concentration on fish muscle to Early fish stage (A), Juvenil (B) and Adult (C) stages 


\section{DISCUSSION}

The fish farms in net cages is an important source of anthropogenic impacts on the reservoirs (STARLING et al. 2002; LAZZARO et al. 2003; GUO et al., 2009), just by the release of dissolved or suspended, and metabolites derived from the remains of the food. These substances associated with the high temperatures favoring an increase in the density of phytoplankton, particularly cyanobacteria blooms (PADISÁK, 1998; CHORUS \& BARTRAM, 1999, REYNOLDS et al. 2002). However one of the most damaging consequences of blooms of cyanobacteria is the incorporation of cyanotoxins in different trophic levels (plankton, fish and man) (MAGALHÃES et al., 2001; VASCONCELOS et al., 2013).

MCYST had accumulated in muscle of all fish sampled. Tilapia can diminish their grazing rate when feeding on toxic cyanobacterial cells (KESHAVANATH et al., 1994). But, in the present study, faced with chronic exposure, tilapia can not prevent the ingestion of toxins, which resulted in the accumulation of microcystin in fish tissues.

Our results demonstrated that most MCYST concentration on early life stage of fish. This is possible because smaller fish seem to accumulate more toxin, due to its size thin epithelial layer in combination with a relatively large body surface (Malbrouck and KESTMONT 2006; DEBLOIS et al. 2011). Concurrently, the purification of cyanotoxins in organisms from the earliest stages of life also seems to be faster, due to changes in their metabolism because as noted, juvenile fish had a lower concentration, and adult levels were even lower.

Chronic exposure to toxic species of cyanobacteria fish held in experiments show the possibility of accumulation of toxin in the muscle (SOARES et al., 2004). Results Cazenave et al. (2005) had microcystin in the muscle of the fish after 24 hours of exposure, with the concentration increasing with time. Moreover, Adamovsky et al. (2007) concluded that in the first weeks of exposure was highest concentration of microcystins and prolonged a less significant increase.

It is also seen that the clearance in the muscles is slower than the other contaminated organs, as demonstrated by Dong et al. (2009), where a clear decrease in the concentration of cyanotoxins was observed in the liver, kidney and intestine but not in muscle. Thus, it is possible to explain the presence of microcystin in adult fish muscle in lower concentrations.

The analyzes carried out in fish stomachs showed a high cyanobacteria density revealing that there is a preference of Nile tilapia by these organisms, this fact was also observed by other authors (DEBLOIS et al, 2011;.. ISSAM et al, 2011). In the work of Chen et al. (2006) found a high percentage of Microcystis cells in the intestinal content of the silver carp, was also observed a significant correlation between the concentration of microcystin, similar to the results presented especially with young life stage.

The residence time or purification of toxins in the body can vary as much due to the metabolism of the fish and their stage of life, but also for the existing variant in the individual. The decrease of microcystin concentrations in tissues can be associated with excretion via the faeces (CHEN et al., 2006). Al- Kahtam \& Fathi (2008), after checking microcystin accumulation in liver and muscle tilapia observed decrease in concentration in the washout period and increased in the concentration of toxins in the feces of organisms.

Even though the liver organ where the highest concentrations of cyanotoxins, it is important to consider and remain alert to the possibility of accumulation also in the muscles which is the part consumed by the population. The World Health Organization (WHO) recommends the tolerable daily intake limit (TDI) of 0.04 microg. $\mathrm{kg}^{-1}$ and Magalhães et al. (2001) in his work on the Jacarepagua lagoon in Rio de Janeiro found levels of microcystin in fish muscles above what is allow the WHO.

It is important remember that cyanobacteria species most abundant were $C$. raciborskii and Planktothrix which also producing saxitoxin, perhaps for this reason our results were lower and did not exceed this limit. However the continuous monitoring is valid as it was proved the existence of microcystin in fish muscles even in small quantities. Cazenave et al. (2005) speaks of the risk of contamination in children or people with less weight than the above, thus alerting to possible contamination even if it is lower the existing concentration. 
The monitoring of the reservoirs about the seasonality, as happens more intense cyanobacteria also is relevant because in that period can happen concurrently production or increase in the concentrations of toxins. Thus, should be avoided consumption of fish when it confirmed the presence of microcystin already in the water. Both the control of eutrophication and the proper management of fish farming activity can serve as preventive measures in controlling algal blooms and their consequent risks to public health.

\section{REFERENCES}

[1] Paerl, H.W., Fulton, R.S., Moisander, P.H., Dyble, J. 2001. Harmful freshwater algal blooms, with an emphasis on cyanobacteria. Sci. World J. 1, 76-113.

[2] Barbosa, J. E. L., Medeiros, E. S. F., Brasil, J., Cordeiro, R. S., Crispim, M.C.B, Silva, G.H.G. 2012. Aquatic systems in semi-arid Brazil: limnology and management. Acta Limnologica Brasiliensia, 24(1), 103-118.

[3] Magalhães, V. F., Marinho, M. M., Domingos, P., Oliveira, A., C., Costa, S. M., Azevedo, L. O. and Azevedo, S. M. F. O. 2003. Microcystins (cyanobacteria hepatotoxins) bioaccumulation in fish and crustaceans from Sepetiba Bay (Brasil, RJ). Toxicon 42, 289-295.

[4] Soares RM, Magalhães, V. F., Azevedo, S. M. F. O. 2004. Accumulation and depuration of microcystins (cyanobacteria hepatotoxins) in Tilapia rendalli (Cichlidae) under laboratory conditions. Aquat Toxicol 70, 1-10.

[5] Karjalainen, M., Reinikainen, M., Spoof, L., Meriluoto, J. A. O., Sivonen, K. and Viitasalo, M. 2005. Trophic transfer of cyanobacterial toxins from zooplankton to planktivores: Consequences for pike larvae and mysid shrimps. Environmental Toxicology And Chemistry 20, 354-362.

[6] Gérard, C., Poullain, V., Lance, E., Acou, A., Brient, L and Carpentier, A. 2009. Influence of toxic cyanobacteria on community structure and microcystin accumulation of freshwater molluscs. Environmental Pollution 157, 609-617.

[7] Berry, J. P. and Lind, O. 2010. First evidence of "paralytic shellfish toxins" and cylindrospermopsin in a Mexican freshwater system, Lago Catemaco, and apparent bioaccumulation of the toxins in "tegogolo" snails (Pomacea patula catemacensis). Toxicon, 55, 930-938.

[8] Deblois C.P., Giani, A., Bird, D. F. 2011. Experimental model of microcystin accumulation in the liver of Oreochromis niloticus exposed subchronically to a toxic bloom of Microcystis sp. Aquat Toxicol 103(1-2), 63-70.

[9] Vasconcelos, J F, Barbosa, J. E. L., Lira, W.M, Azevedo, S.M.F.O. 2013. Microcystin bioaccumulation can cause potential mutagenic effects in farm fish. The Egyptian Journal of Aquatic Research, 39, 185 - 192.

[10] Magalhães VF, Soares, R.M., Azevedo, S.M.F.O. 2001. Microcystin contamination in fsh from the Jacarepaguá (RJ, Brazil): ecological implication and human health risk. Toxicon 39, 10771085.

[11] [11] Attayde, J . L ., Brasil, J . and Menescal, R . A. 2011. Impacts of introducing Nile tilapia on the fisheries of a tropical reservoir in North-eastern Brazil. Fisheries Management And Ecology, (18-6), 437-443.

[12] Lazzaro, X. 1987. A review of planktivorous fishes: Their evolution, feeding behaviours, selectivities, and impacts. Hydrobiologuia 146, 97-167.

[13] Chen, J., Xie, P., Zhang, D., Ke, Z. and Yang, H. 2006. In situ studies on the bioaccumulation of microcystins in the phytoplanktivorous silver carp (Hypophthalmichthys molitrix) stocked in Lake Taihu with dense toxic Microcystis blooms. Aquaculture 261, 1026-1038.

[14] Dietrich, D., Hoeger, S. 2005. Guidance values for microcystinsin water and cyanobacterial supplement products (blue-green algal supplements): A reasonable or misguided approach? Toxicol and Appl Pharmacol 203, 273-289.

[15] APHA. 1992. Standard methods for the examination of water and wastewater. Washington, DC: American Public Health Association. p.1220.

[16] APHA. 1995. Standard methods for the examination of water and wastewater. Washington, DC.: American Public Health Association. p.1220. 
[17] Utermöhl H. 1958. Zur Vervollkomnung der quantitativen Phytoplankton-Methodik Mitteillung. Verhandlungen des Internationalen Verein Limnologie 9, 1-38.

[18] Komarek J, Agnostidis, K. 1986. Modern approach to the classification system of cyanophites 2chroococcales. Archives of Hydrobiology Algol Studies 43(Suppl 73), 157-226.

[19] Baker P. 1991. Urban Water Research Association of Australia. Identification of Common Noxious Cyanobacteria, Part1: Nostocales. Australian Centre for Water Treatment and Water Quality Research. Research Report 29. Melbourne and Metropolitan Board of Works.

[20] Baker P. 1992. Urban Water Research Association of Australia. Identification of Common Noxious Cyanobacteria, Part2: Chroococcales, Oscillatoriales. Australian Centre for Water Treatment and Water Quality Research. Research Report 46, Melbourne Water Corporation.

[21] Starling F, Lazzaro X., Cavalcanti, C., Moreira R. 2002. Contribution of omnivorous tilapia to eutrophication of a shallow tropical reservoir: evidence from a fish kill. Freshwater Biol 47(12), 2443-2452.

[22] Lazzaro X, Bouvy, M., Ribeiro-Filho, R.A., Oliveira, V.S., Sales, L.T., Vasconcelos, A.R.M., Mata, M.R.,. 2003. Do fish regulate phytoplankton in shallow eutrophic Northeast Brazilian reservoirs. Freshwater Biol 48, 649-668.

[23] Guo L, Zhongjie, L., Xie, P., Ni, L., 2009. Assessment effects of cage culture on nitrogen and phosphorus dynamics in relation to fallowing in a shallow lake in China. Aquacult Internat 17, 229-241.

[24] Padisák J, Reynolds, C.S. 1998. Selection of phytoplankton associations in Lake Balaton, Hungary, in response to eutrophicatioon and restoration measures, with special reference to cyanoprokaryotes. Hydrobiologia 384, 41-53.

[25] Chorus I, Bartram, J. 1999. Toxic Cyanobacteria in water: A guide to the Public Health Consequences, Monitoring and Management. London: E \& FN Spon.

[26] Reynolds C. S, Huszar, V., Kruk, C., Naselli-Flores, L., Melo, S. 2002. Towards a functional classification of the freshwater phytoplankton. J Plankt Res 24, 417-428.

[27] Keshavanath P, Beveridge, M. C. M., Baird, D. J., Lawton, L. A., Nimmo, A., Codd, G. A.,. 1994. The functional grazing response of a phytoplanktivorous fish Oreochromis niloticus to mixtures of toxic and non-toxic strains of the cyanobacterium Microcystis aeruginosa. J Fish Biol 45, 123-129.

[28] Malbrouck, C. and Kestemont, P. 2006. Effects of microcystins on fish. Environmental Toxicology And Chemistry, Santiago (25-1), 72-86.

[29] Cazenave, J., Wunderlin, D. A., Bistoni, M. A., Amé, M. V., Krause, E., Pflugmacher, S. and Wiegand, C. 2005. Uptake, tissue distribution and accumulation of microcystin-RR in Corydoras paleatus, Jenynsia multidentata and Odontesthes bonariensis A field and laboratory study. Aquatic Toxicology 75, 178-190.

[30] Adamovsky, O., Kopp, R., Hilscherová, K., Babica, P., Paliková, M., Pasková, V., Navrátil, S., Marsálek, B. and Bláha, L. 2007. Microcystin kinetics (bioaccumulation and elimination) and biochemical responses in common carp (Cyprinus carpio) and silver carp (Hypophthalmichthys molitrix) exposed to toxic cyanobacterial blooms. Environmental Toxicology And Chemistry (26-12), 2687-2693.

[31] Dong, G., Zhu, X., Han, D., Yang, Y., Song, L. and Xie, S. 2009. Effects of dietary cyanobacteria of two different sources on growth and recovery of hybrid tilapia (Oreochromis niloticus O. aureus). Toxicon 54, 208-216.

[32] Issam, El G., Saqrane, S., Carvalho, A. P., Ouahid, Y., Del Campo, F. F., Oudra, B. and Vasconcelos, V. 2011. Effect of different microcystin profiles on toxin bioaccumulation in common carp (Cyprinus carpio) larvae via Artemia nauplii. Ecotoxicology and Environmental Safety 73, 762-770.

[33] Al-Kahtani, M. A. and Fathi, A. 2008. Physiological studies on tilapia fish (Oreochromis niloticus) as influenced by the cyanobacterial toxins microcystin. Journal of Biological Sciences (8-7), 1226-1230. 


\section{AUTHORS' BIOGRAPHY}

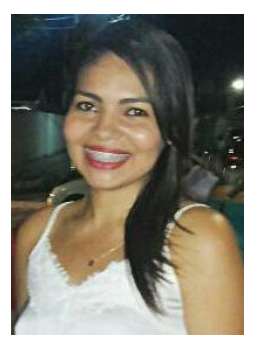

Camila Ferreira Mendes, is $\mathrm{PhD}$ in Environmental Engineering from the Universidade Estadual da Paraíba Has experience in Ecology, with emphasis on Aquatic Ecosystems Ecology and Toxins of Cyano bacteria.

José Etham de Lucena Barbosais, associate professor at the Universidade Estadual da Paraíba. Has experience to clarify limno logical aspects, operating mechanisms and management of the river basin of the Paraiba River and aquatic biodiversity with emphasis on Cyano bacteria and eutrophication processes in dams Semi-Arid.

JanieleFrança Nery, is $\mathrm{PhD}$ in Ecology Aquatic Ecosystems. Has experience in ecology/limnology, with emphasis on Cyano bacteria, acting on the following topics: alternative stable states, ecology of plankton communities, dynamic reservoirs, eutrophication of aquatic ecosystems and toxicology of cyano bacteria and modeling of non linear systems. 